\title{
Trachelomonas bituricensis var. lotharingia M.L. Poucques 1952, a morphologically interesting, rare euglenoid new to the algal flora of the Czech Republic
}

\author{
Josef Juráň 1,2 \\ I Department of Botany, Faculty of Science, University of South Bohemia, Na Zlaté Stoce 1, České Budéjovice \\ CZ-37005, Czech Republic 2 Centre for Phycology, Institute of Botany AS CR, Dukelská 135, Treboň CZ- \\ 37982, Czech Republic
}

Corresponding author: Josef Juráňn (juran.josef@seznam.cz)

Academic editor: E. Cooper | Received 4 December 2015 | Accepted 25 January 2016 | Published 25 February 2016

Citation: Juráń J (2016) Trachelomonas bituricensis var. lotharingia M.L. Poucques 1952, a morphologically interesting, rare euglenoid new to the algal flora of the Czech Republic. PhytoKeys 61: 81-91. doi: 10.3897/phytokeys.61.7408

\begin{abstract}
This report describes the discovery of the rare euglenoid taxon Trachelomonas bituricensis var. lotharingia in a small mesotrophic pond in the Czech Republic. Only limited data are available on the distribution of this taxon as same as for typical variety of Trachelomonas bituricensis, even though this taxon is morphologically very well defined. I provide a brief discussion of the taxonomic validity of this taxon based only on morphological features, which are characteristic for the taxonomy of the genus Trachelomonas. This finding is completely new for the algal flora of the Czech Republic. This report provides new information about the worldwide distribution of this taxon and its ecology.
\end{abstract}

\section{Keywords}

Czech Republic, floristics, microalgae, Trachelomonas

\section{Introduction}

Floristics studies have had a long tradition in the Czech Republic beginning in the second half of the 19th century, when several works about alga flora in this country were published. Since the publication of pioneering works by Kirchner (1878) and 
Hansgirg (1892, 1899), Lhotský and Rosa (1955) published a list of algal and cyanobacterial species from the Moravia region. The current knowledge about algal diversity in this region was summarised by Poulićková et al. (2004). All of these reports describe floristic studies examining the prevalence of all groups of algae in our state. These studies, combined with recent reports about the distribution of various groups of algae (e.g., Caisová and Gąbka 2009, Kaštovský et al. 2010, Kučera et al. 2008 and Štastný 2010), provide comprehensive information about algal flora. Unfortunately, little is known about several of these groups and their distribution, e.g., diatoms, dinophytes and euglenoids.

I performed a nearly 5 year survey during my bachelors and masters studies investigating the diversity of photosynthetic euglenophytes (Juráň 2010, 2012) based on extensive literature reviews and my own floristic studies across the country. As a result, I constructed a preliminary checklist of euglenoid taxa of the Czech Republic including several species that were newly reported in our state. This checklist will be published soon. One of these new species is Trachelomonas bituricensis var. lotharingia from Ďáblík pond in South Bohemia.

The genus Trachelomonas includes euglenoids with their cells enclosed in envelopes (loricas) comprising polysaccharides with a content of iron and several inorganic compounds (Pereira et al. 2003). These loricas are highly variable in shape and surface morphology. Listed features are traditional markers used in Trachelomonas taxonomy, as proposed by Deflandre (1926). Since the original description of Trachelomonas by Ehrenberg (1834), more than 1700 taxa have been identified due to this high morphological variability in the genus (Guiry and Guiry 2015).

Trachelomonas bituricensis was originally described by Wurtz (1947), who identified this species in plankton from the pond of the Hardouine in La Brenne, France. In the typical species, the lorica is covered with long, sharp, curved spines. One variety of this species, Trachelomonas bituricensis var. lotharingia, was first described by Poucques (1952). The description of new taxon was based on material from a wetland in the Woëvre region in France. This variety has shorter collars (see Fig. 3) than the typical forma described by Wurtz (1947). In addition, the edge of the collar is more undulated.

\section{Methods}

The aim of this study was to survey the algal flora of the small mesotrophic pond D́áblík (South Bohemia region, Czech Republic, 4849'41.0"N, 14³5'49.6"E, see Figs 1 and 2). This habitat is a small pond that functions as a primary retention pond, without fishery management. This pond contains huge communities of Carex spp. and Sphagnum spp. and a stable population of the charophycean alga Nitella flexilis. The pond is progressively becoming overgrown with vegetation. The locality is favourable for the growth of threatened vascular plants, e.g., Nymphaea candida, Calla palustris and Menyanthes trifoliata. Wetland plants Utricularia australis and Potamogeton obtusifolius are common in this locality (Albrecht 2003). 


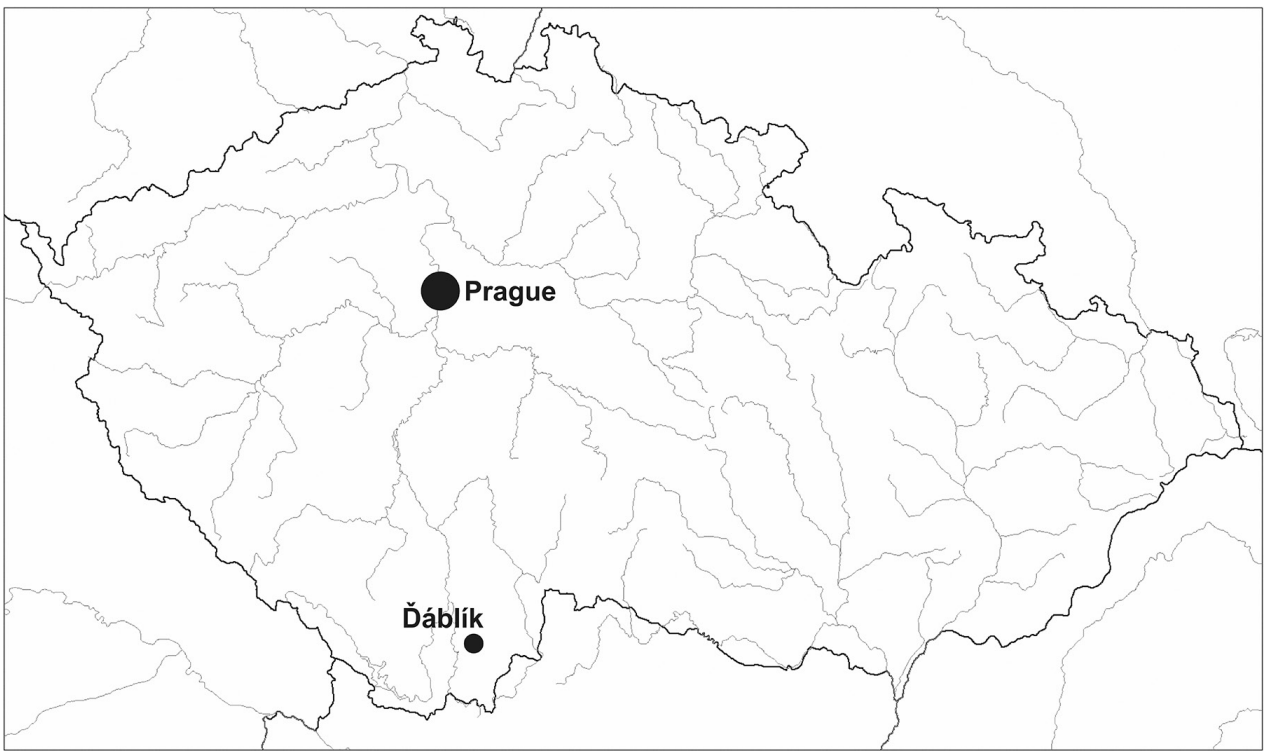

Figure I. Location of the studied locality.

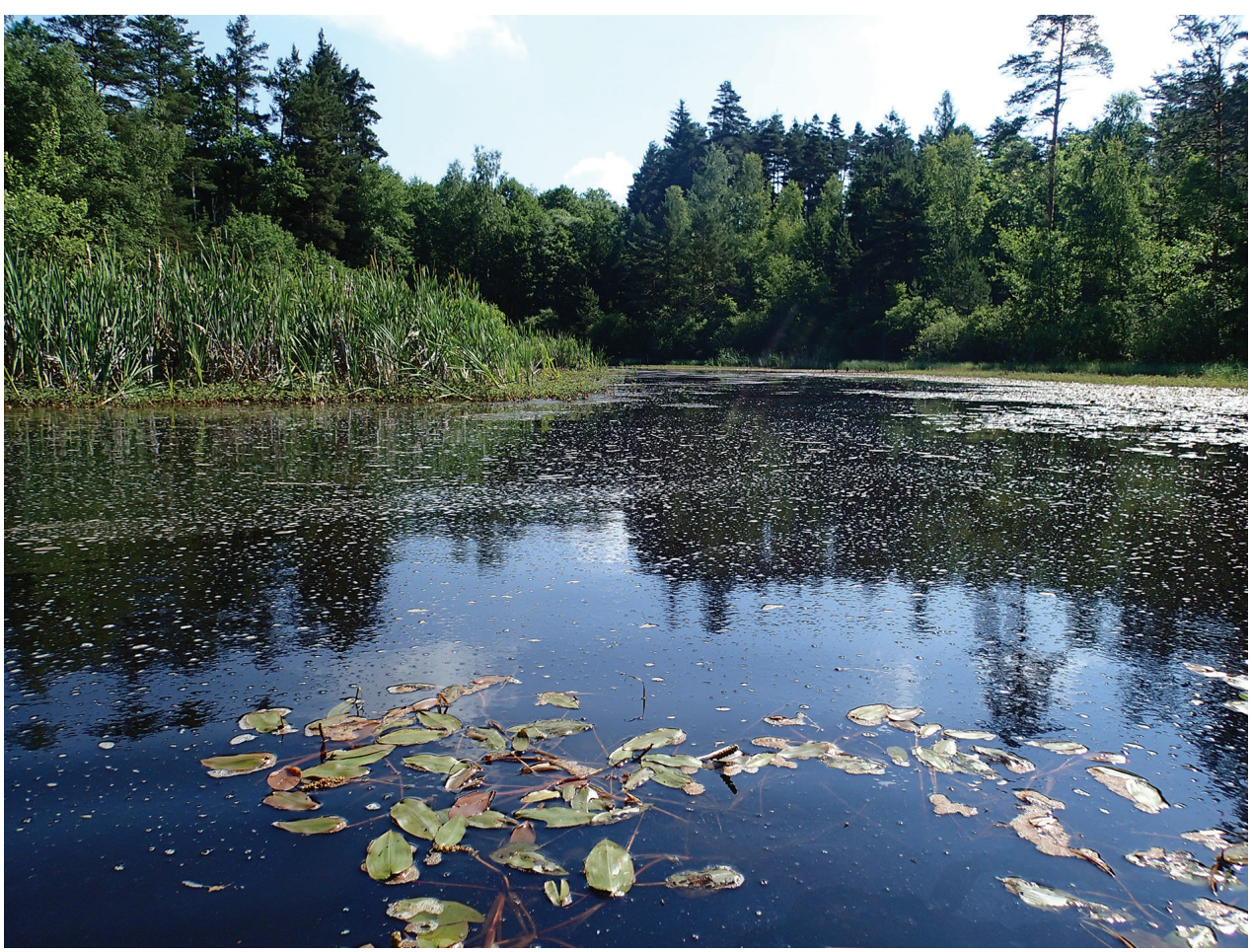

Figure 2. Photograph of a free water surface with knotweed (Potamogeton sp., at the front) and Carex spp., together with Sphagnum spp. communities (left). 
In 2012 and 2013, a pilot survey was taken, and in 2014, a more detailed survey with monthly sampling at five chosen locations was performed. The aim of this survey was to record algal diversity, especially for loricate euglenoid genera Trachelomonas and Strombomonas. Samples were taken using a $20 \mu \mathrm{m}$ plankton net, and the material was fixed in formaldehyde solution and Lugol's iodine solution. Samples were examined microscopically under an Olympus BX51 microscope and photographed with an Olympus DP-71 camera with DP Controller 3.1.267 software. Samples fixed in iodine solution were used for scanning electron microscopy. Materials for scanning electron microscopy were prepared as described by Conforti (2009). The material was filtered through polycarbonate membrane filters $(1 \mu \mathrm{m}$ pore size $)$ and air-dried. Filter pieces were attached to stubs and subsequently coated with gold. The specimens were then saved for future scanning electron microscopy analysis or examined under a JEOL JSM-7401F scanning electron microscope (Institute of Parasitology, Biology centre of AS CR, České Budějovice).

\section{Results}

The algal flora of the Dáblík pond is dominated by dinophytes (Peridinium spp.), together with desmids and metaphytic communities of Spirogyra spp. steril., as well as diatoms (especially Gomphonema species). Taxon-rich flora of the loricate euglenoids will be studied in detail using optical and scanning electron microscopy in conjunction with comparisons of the chemical and physical parameters of pond water. Based on the preliminary results, some of the taxa appear to represent new algal flora of the Czech Republic, but these taxa require further study. The most interesting finding is the discovery of Trachelomonas bituricensis var. lotharingia, a newly recorded variety of algal flora in the Czech Republic. This variety is quite common in Dáblík pond, which contains a stable population of this alga. This finding represents the first record of this taxon among algal flora of the Czech Republic based on a detailed literature review and the floristic survey across the Czech Republic that I performed during my bachelors and masters studies (Jurán 2010, 2012).

The loricas in this species are $(41-) 45-46 \mu \mathrm{m}$ in length and $(30-) 33-35 \mu \mathrm{m}$ wide. The cell contains numerous disc-like chloroplasts, probably without pyrenoids. The surface of the lorica in this taxon from Dáblík pond is punctate and covered with well-developed hollow, sharp spines (see Fig. 3A-D), most of which are slightly curved and cover the body of the lorica. The caudal region contains very long, curved spines, and only a few narrow, conical spines surround the apical pore, which has a collar (see Fig. 3B, marked with arrows). The collar of the lorica is short, with an undulated edge (see Fig. 3D, marked with arrow). This taxon has always been found during the spring at shallow sites with populations of Nitella flexilis near the banks of the pond. These findings suggest that Trachelomonas bituricensis var. lotharingia is probably a benthic or metaphytic taxon. 

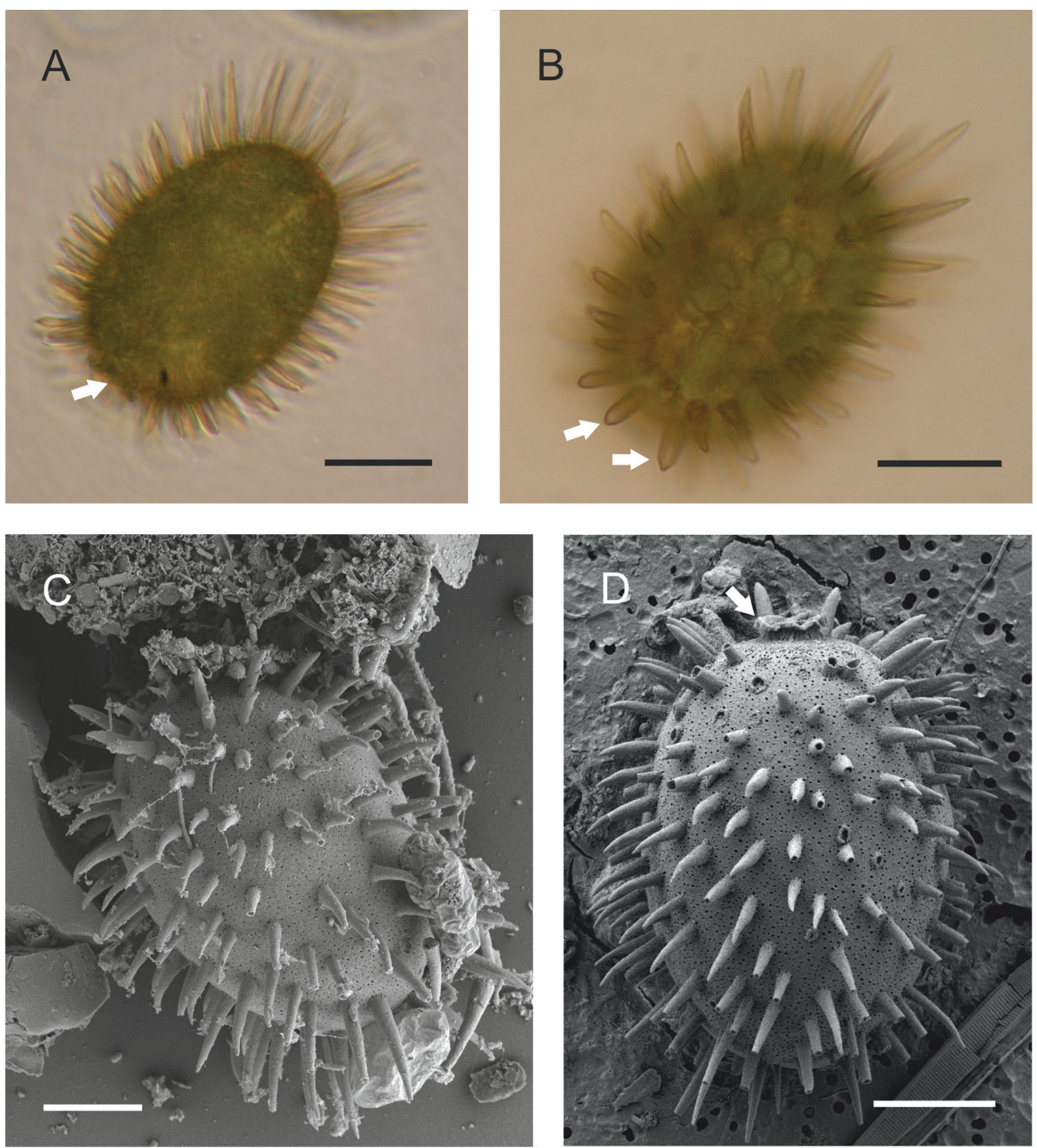

Figure 3. Visualisation of the morphology of Trachelomonas bituricensis var. lotharingia by optical and electron scanning microscopy. A Overall appearance of lorica under an optical microscope, with a short collar with undulated edge (marked with arrow) B Detailed image of the lorica surface with three types of spines: long, curved spines at the antapical part of the lorica; shorter spines on the lorica's body; and several straight spines near the apical pore (marked with arrows). Note the numerous disc-like chloroplasts in the cell C, D Loricas viewed by scanning electron microscopy, with clearly visible punctuation at the surface, and short collar with undulated edge (marked with arrow). Scale bars $=10 \mu \mathrm{m}$.

A comparison of a typical variety of Trachelomonas bituricensis, the variety described by Poucques (1952) and the material found in Dáblík pond is presented in Table 1. 
Table I. Comparison of morphological data about Trachelomonas bituricensis taxa.

\begin{tabular}{|c|c|c|c|}
\hline Feature & Wurtz (1947) & Poucques (1952) & This study \\
\hline Shape & & ellipsoidal to ovoid & ellipsoidal \\
\hline Length $^{*}$ & $40 \mu \mathrm{m}$ & $40 \mu \mathrm{m}$ & $(41-) 45-46 \mu \mathrm{m}$ \\
\hline Width $^{*}$ & $20 \mu \mathrm{m}$ & $30 \mu \mathrm{m}$ & $(30-) 33-35$ \\
\hline $\begin{array}{l}\text { Spine length } \\
\text { - conical spines } \\
\text { - posterior part }\end{array}$ & $\begin{array}{l}\text { N/A } \\
\text { N/A }\end{array}$ & $\begin{array}{c}4-6 \mu \mathrm{m} \\
12-14 \mu \mathrm{m}\end{array}$ & $\begin{array}{c}4-5 \mu \mathrm{m} \\
8-13 \mu \mathrm{m}\end{array}$ \\
\hline Collar & $\begin{array}{l}\text { slightly enlarged, with } \\
\text { thickening at the base }\end{array}$ & $\begin{array}{c}\text { short, large, regular } \\
\text { undulated edge }\end{array}$ & $\begin{array}{l}\text { short collar with } \\
\text { undulated edge }\end{array}$ \\
\hline Chloroplasts & N/A & N/A & numerous, discoid \\
\hline Ecology & fishpond; plankton & wetland; plankton & $\begin{array}{l}\text { mesotrophic pond; } \\
\text { benthos, metaphyton }\end{array}$ \\
\hline
\end{tabular}

*without spines

\section{Discussion}

These two taxa (Trachelomonas bituricensis and Trachelomonas bituricensis var. lotharingia) are commonly mentioned in works about euglenophytes (e.g., Huber-Pestalozzi 1955, Popova 1966, Starmach 1983 and Vetrova 1986). These taxa have distinct morphology that is easy to distinguish from that of other species, the descriptions of which are commonly used in taxonomic keys. However, data about the occurrence of these taxa are very limited. A typical form of Trachelomonas bituricensis was only recently reported to occur in several places, including benthos in a fishpond in Poleski National Park, Poland (Kočárková et al. 2002) and two rivers in Kosovo (Kurteshi et al. 2013a, 2013b). The second reported location of lotharingia variety was a bog in the Russian taiga, where this taxon was found in a wetland containing saw grass (Carex sp.) (Safonova 1987). In addition, Vetrova (1986) identified this variety among algal flora of Ukraine. Perhaps the most recently reported occurrence of this taxon was in the Southeastern US, where it was rarely observed in ditches, lakes and ponds (Wolowski and Walne 2007).

Several species of Trachelomonas have the similar morphology as Trachelomonas bituricensis. The most resembling taxa are Trachelomonas horrida, which was first described by Palmer (1905), as well as T. megalacantha (DaCunha, 1914) and T. spectabilis (Deflandre, 1926). All of these species have loricas covered with well-developed long, sharp spines, but their spines are straight, unlike the curved spikes on the loricas of Trachelomonas bituricensis. Huber-Pestalozzi (1955) argued that Trachelomonas bituricensis var. lotharingia is highly similar to Trachelomonas spinosa, which is found in ponds containing aquatic plants (Stokes 1890), and that it probably represents a larger form of these taxa. Stokes' (1890) description of the surface and shape of the Trachelomonas spinosa lorica is similar to that of Trachelomonas bituricensis, whereas its collar is described as a "... short, smooth, truncate extension", with no mention of the undulated edge or additional cylindrical spines. In addition, Tell and Conforti (1986) described 
Trachelomonas spinosa from Argentina as having a similar morphology, with an apical pore with a short, thick neck surrounded by spines; again, an undulated edge is not mentioned. Vetrova (1986) noted the similarity between Trachelomonas bituricensis and lotharingia-variety with $T$. horrida and $T$. spinosa, although they did not mention the taxonomy of Trachelomonas bituricensis taxa in a subsequent report and the validity of this variety could be discussed. Finally, Wolowski and Walne (2007) reported that Trachelomonas bituricensis var. lotharingia from the US has a dentate collar.

The high morphological variability of the genus Trachelomonas makes classification based only on morphology (e.g., shape, surface, absence or presence of various forms of collar and sometimes colour of the lorica) quite difficult and has led to the description of morphologically similar forms as separate taxa. As a result of morphological variability, the traditional taxonomy of Trachelomonas based only on a description of lorica characters is problematic for several reasons. First, there are several examples of the morphology of euglenoids changing depending on environmental conditions. This variability in shape was observed in several euglenoid genera in culture (Conforti 1998) and those cultivated in situ under natural conditions (Bauer et al. 2012). The cells of these taxa exhibited morphological changes depending on the level of organic carbon in the medium or the environment. Pringsheim (1953) and Singh (1956a, b) found that in some Trachelomonas species, the loricas of cells in clonal culture (i.e., descendants of a single cell) have morphological diversity in shape and surface, which probably depends on their specific ontogeny. This diversity represents the main problem with classification based solely on morphology. Indeed, in discussing Euglena taxonomy, Pringsheim (1956) noted that, "Certain authors could not resist the temptation to give a name to every minor deviation from the 'type' previously described or prevailing at the same or at similar places". This comment accurately describes the state of taxonomy of the genus Trachelomonas. Therefore, the large number of currently described taxa within the genus Trachelomonas likely reflects the morphological variability created by environmental conditions. Many of these taxa may instead be recognised as "eco-morphs" of the typical form. Furthermore, Pringsheim $(1953,1956)$ claimed that unless individual species are cultured separately, the effects of external factors affecting heritable morphological traits cannot be distinguished. In light of these findings, perhaps Trachelomonas bituricensis var. lotharingia is only an eco-morph of the typical forma, or perhaps it represents a bituricensis eco-morph of Trachelomonas spinosa. Alternatively, this alga may represent a complex of species. More detailed morphological studies are needed to solve this taxonomic puzzle, including basic morphometric analysis and especially molecular analysis.

Many reports about euglenoid taxonomy based on morphological and molecular data (e.g., Karnkowska-Ishikawa et al. 2010, 2011, 2012, 2013 and Kosmala et al. 2005, 2007a, 2007b, 2009) show that several species or other intraspecific taxa may instead only represent eco-morphs or ontogenetic stages of individual species, as discussed in a report about Monomorphina genus taxonomy (Kosmala et al. 2007b). Unfortunately, similar studies about the taxonomy of the genus Trachelomonas remain to be performed. Several recent works (e.g., Nejmová et al. 2011, Škaloud et al. 2015 and 
Veselá et al. 2012) about species concept in algae reflect a combination of molecular and morphological data. Therefore, a combination of ecological, morphological and molecular data can be used to define the species concept of a genus with worldwide distribution such as Trachelomonas. However, this issue requires further study.

\section{Conclusion}

This report describes what is likely the third record of Trachelomonas bituricensis var. lotharingia in Europe and the first record of this taxon in the Czech Republic. The description of this taxon is morphologically and ecologically similar to the original description. The taxonomic validity of this taxon remains to be validated, as it may represent part of a complex of morphologically similar species together with T. spinosa and T. horrida. Nonetheless, the discovery of this taxon sheds light on the distribution of algae of the Czech Republic and European algal flora in general.

\section{References}

Albrecht J (2003) Chráněná území ČR. VIII., Českobudějovicko. Agentura ochrany př́ŕody a krajiny ČR, $1-807$.

Bauer DE, Conforti V, Ruiz L, Gomez N (2012) An in situ test to explore the responses of Scenedesmus acutus and Lepocinclis acus as indicators of the changes in water quality in lowland streams. Ecotoxicology and Environmental Safety 77: 71-78. doi: 10.1016/j.ecoenv.2011.10.021

Caisová L, Gąbka M (2009) Charophytes (Characeae, Charophyta) in the Czech Republic: taxonomy, autecology and distribution. Fottea 9(1): 1-43. doi: 10.5507/fot.2009.001

Conforti V (1998) Morphological changes of Euglenophyta in response of organic enrichment. Hydrobiologie 369: 277-85. doi: 10.1023/A:1017049910481

Conforti V (2009) Floristic and ultrastructural study of the genus Strombomonas (Euglenophyta) from New Jersey fresh waters. Algological Studies 132(1): 1-20. doi: 10.1127/18641318/2009/0132-0001

DaCunha AM (1914) Contribuição para o conhecimento da fauna de Protozoarios do Brazil. Memórias do Instituto Oswaldo Cruz 6: 169-179. doi: 10.1590/S007402761913000200001

Deflandre G (1926) Monographie du genre Trachelomonas Ehr. A. Lesot, Nemours, 1-162. Ehrenberg CG (1834) Dritter Beitrag zur Erkenntniss grosser Organisation in der richtung des kleinsten Raumes. Abhandlungen der Königlichen Akademie der Wissenschaften zu Berlin 1833: 145-336.

Guiry MD, Guiry GM (2015) AlgaeBase. World-wide electronic publication, National University of Ireland, Galway. http://www.algaebase.org [searched on 22 October 2015]

Hansgirg A (1892) Prodromus českých řas sladkovodních. Díl druhý obsahující, Řasy siné (Myxophyceae, Cyanophyceae) s dodatky k prvnímu dílu, sladkovodními bakteriemi a euglenami. Archiv pro prrírodovědecký výzkum Čech, 1-182. 
Hansgirg A (1899) Prodromus českých řas sladkovodních. Díl prvý obsahující, Řasy rudé (Rhodophyceae), smědé (Phaeophyceae) a zelené (Chlorophyceae). Archiv pro prŕrodovědecký výzkum Čech, Praha, 1-182.

Huber-Pestalozzi G (1955) Das Phytoplankton des Süsswassers: Systematik und Biologie. 4. Teil, Euglenophyceen. Schweizerbart, 606 pp.

Juráň J (2010) Euglenophytes of the Czech Republic in view of South Bohemia and the Bohemian Forest. Bachelor Thesis, University of South Bohemia in České Budějovice, Czech Republic.

Jurán J (2012) Pilot study on the issue of Euglenophyta in the Czech Republic. Master Thesis, University of South Bohemia in České Budějovice, Czech Republic.

Karnkowska-Ishikawa A, Milanowski R, Kwiatowski J, Zakryś B (2010) Taxonomy of the Phacus oscillans (Euglenaceae) and its close relatives-balancing morphological and molecular features. Journal of Phycology 46(1): 172-182. doi: 10.1111/j.1529-8817.2009.00765.x

Karnkowska-Ishikawa A, Milanowski R, Triemer RE, Zakryś B (2012) Taxonomic Revisions of Morphologically Similar Species from Two Genera: Euglena (E. granulata and E. velata) and Euglenaria (Eu. anabaena, Eu. caudata, Eu. clavata). Journal of Phycology 48(3): 729-739. doi: 10.1111/j.1529-8817.2012.01140.x

Karnkowska-Ishikawa A, Milanowski R, Triemer RE, Zakryś B (2013) A redescription of morphologically similar species from the genus Euglena: E.laciniata, E.sanguinea, E.sociabilis, and E.splendens. Journal of Phycology 49(3): 616-626. doi: 10.1111/jpy.12072

Karnkowska-Ishikawa A, Milanowski R, Zakryś B (2011) The species Euglena deses (Euglenaceae) revisited: new morphological and molecular data. Journal of Phycology 47(3): 653-661. doi: 10.1111/j.1529-8817.2011.00982.x

Kaštovský J, Hauer T, Komárek J, Skácelová O (2010) The list of cyanobacterial species of the Czech Republic to the end of 2009. Fottea 10(2): 245-249. doi: 10.5507/fot.2010.015

Kirchner O (1878) Algen. In: Cohn F (Ed.) Kryptogamen-Flora von Schlesien. J. U. Kern's Verlag, Břeclav, 1-282.

Kočárková A, Hekera P, Rulík M (2002) Contribution to the knowledge of the algae from wetland of Poleski National Park (east Poland). Czech Phycology 2: 68-74.

Kosmala S, Bereza M, Milanowski R, Kwiatowski J, Zakryś B (2007a) Morphological and molecular examination of relationships and epitype establishment of Phacus pleuronectes, Phacus orbicularis and Phacus hamelii. Journal of Phycology 43(5): 1071-1082. doi: 10.1111/j.1529-8817.2007.00386.x

Kosmala S, Milanowski R, Brzóska K, Pekala M, Kwiatowski J, Zakryś B (2007b) Phylogeny and systematics of the genus Monomorphina (Euglenaceae) based on morphological and molecular data. Journal of Phycology 43(1): 171-185. doi: 10.1111/j.1529-8817.2006.00298.x

Kosmala S, Karnkowska A, Milanowski R, Kwiatowski J, Zakryś B (2005) Phylogenetic and taxonomic position of Lepocinclis fusca comb. nov. (= Euglena fusca) (Euglenaceae): morphological and molecular justification. Journal of Phycology 41(6): 1258-1267. doi: 10.1111/j.1529-8817.2005.00141.x

Kosmala S, Karnkowska-Ishikawa A, Milanowski R, Kwiatowski J, Zakryś B (2009) Phylogeny and systematics of Euglena (Euglenaceae) species with axial, stellate chloroplasts based on morphological and molecular data - new taxa, emended diagnoses, and epitypifications. Journal of Phycology 45(2): 464-481. doi: 10.1111/j.1529-8817.2009.00653.x 
Kučera P, Grulich V, Fránková M, Bureš P (2008) Distribution of freshwater red algal family Lemaneaceae (Rhodophyta) in the Czech Republic: an update. Fottea 8(2): 125-128. doi: $10.5507 /$ fot.2008.010

Kurteshi K, Vehapi I, Ismaili M, Vllasaku I (2013a) Algological investigation in river Nerodime during the summer season 2011. New knowledge Journal of science 2(1): 63-67.

Kurteshi K, Vehapi I, Vllasaku I (2013b) Determination of pollution in river Drini Bardhë during summer season 2010 through the algal bioindicators. New knowledge Journal of Science 2(1): 56-60.

Lhotský O, Rosa K (1955) Soupis moravskoslezských sinic a řas. Československá akademie věd, $1-260$.

Nejmová K, Neustupa J, Štastný J, Škaloud P, Veselá J (2011) Species concept and morphological differentiation of strains traditionally assigned to Micrasterias truncata. Phycological Research 59(3): 208-220. doi: 10.1111/j.1440-1835.2011.00619.x

Palmer TC (1905) Delaware Valley forms of Trachelomonas. Natural Science of Philadelphia 57: 665-675.

Pereira MJ, Azeiteiro UMM, Gonçalves F, Soares AMVM (2003) Inorganic composition of the envelopes of Trachelomonas Ehr. (Euglenophyta). Acta Oecologica 24(S1): 317-324. doi: 10.1016/S1146-609X(03)00027-4

Popova TG (1966) Flora sporovych rastenij SSSR . T.8.: Vyp.1., Evglenovyje vodorosli: Rody Trachelomonas, Strombomonas, Eutreptia, Euglena. Akademija Nauk SSSR, Moskva, 410 pp.

Poucques ML (1952) Étude algologique de l'Étang de la Grange en Woëwre. Révue Generale de Botanique 59: 299-311.

Poulíčková A, Lhotský O, Dřímalová D (2004) Review of cyanobacteria and algae of the Czech Republic. Czech Phycology 4: 19-33.

Pringsheim EG (1953) Observation on Some Species of Trachelomonas Grown in Culture. New Phytologist 52(3): 93-113; 238-66. doi: 10.1111/j.1469-8137.1953.tb07514.x

Pringsheim EG (1956) Contributions towards a monograph of the genus Euglena. Nova Acta Leopoldina 18: 1-168.

Safonova TA (1987) Evglenovyje vodorosli Zapadnoj Sibiri. Nauka, 1-191.

Singh KP (1956a) Studies in the genus Trachelomonas. I. Description of six organisms in cultivation. American Journal of Botany 43(4): 258-266. doi: 10.2307/2438942

Singh KP (1956b) Studies in the genus Trachelomonas. II. Cell structure and reproduction with special reference to T. grandis. American Journal of Botany 43(4): 274-280. doi: $10.2307 / 2438944$

Starmach K (1983) Euglenophyta - Eugleniny. Państwowe Wydawnictwo Naukowe, 1-593.

Stokes AC (1890) Notices of New Fresh-water Infusoria. Proceedings of the American Philosophical Society 28(132): 74-81.

Škaloud P, Steinová J, Ř́dká T, Vančurová L, Peksa O (2015) Assembling the challenging puzzle of algal biodiversity: species delimitation within the genus Asterochloris (Trebouxiophyceae, Chlorophyta). Journal of Phycologi 51: 507-27. doi: 10.1111/jpy.12295

Štastný J (2010) Desmids (Conjugatophyceae, Viridiplantae) from the Czech Republic; new and rare taxa, distribution, ecology. Fottea 10: 1-74. doi: 10.5507/fot.2010.001

Tell G, Conforti V (1986) Euglenophyta pigmentadas de la Argentina. J. Cramer, 1-301. 
Veselá J, Urbánková P, Černá K, Neustupa J (2012) Ecological variation within traditional diatom morphospecies: diversity of Frustulia rhomboides sensu lato (Bacillariophyceae) in European freshwater habitats. Phycologia 51(5): 552-561. doi: 10.2216/11-101.1

Vetrova ZI (1986) Flora algarum aquariorum continentalium RSS Ucrainiceae. Euglenophyta I/1. Naukova dumka, 1-346.

Wołowski K, Walne P (2007) Strombomonas and Trachelomonas species (Euglenophyta) from south-eastern USA. European Journal of Phycology 42(4): 409-431. doi: 10.1080/09670260701702508

Wurtz A (1947) Algues nouvelles et intéressantes des étangs de la Brenne. Bulletin de la Société Botanique de France 94(3-4): 104-114. doi: 10.1080/00378941.1947.10834593 